\title{
Highly Selective and Sensitive Membrane Salicylate Electrode Based on Complex of (1,8-Diamino-3,6-dioxaoctane) Nickel(II)
}

\author{
M. Mazloum-Ardakani, ${ }^{*, a}$ P. Pourhakkak, ${ }^{b}$ M. Salavati-Niasari, ${ }^{c}$ M. A. Karimi ${ }^{d}$ and \\ M. H. Mashhadizadeh \\ ${ }^{a}$ Department of Chemitry, Faculty of Science, Yazd Univesity, Yazd, Iran \\ ${ }^{b}$ Department of Chemistry, Payam Noor University, Ardakan Center, Ardakan, Iran \\ ${ }^{c}$ Department of Inorganic Chemistry, Faculty of Chemistry, University of Kashan, Kashan, Iran \\ ${ }^{d}$ Department of Chemistry, Payam Noor University, Sirjan Center, Sirjan, Iran \\ ${ }^{e}$ Department of Chemitry, Faculty of Science, Tarbiat Moalem Univesity, Tehran, Iran
}

Foi estudada a resposta potenciométrica do eletrodo de salicilato com o complexo (1,8-diamino-3,6-dioxaoctano) de níquel (II). O complexo 1,8-diamino-3,6-dioxaoctano de níquel (II) [Ni(DADOO)] foi suportado em uma membrana contendo policloreto de vinila (PVC), um plastificante e um aditivo. A influência de diversas variáveis foi investigada e a resposta e a seletividade potenciométrica do eletrodo foram otimizadas. O eletrodo de membrana resultante incorpora $29 \%$ de PVC, $63 \%$ dioctilftalato (DOP) como plastificante, $2 \%$ de cloreto de metiltrioctilamônio (MTOAC) como aditivo catiônico e $6 \%$ do ionóforo carregador $(\mathrm{m} / \mathrm{m})$. Demonstrou uma resposta de Nernstiana de $-59,5 \pm 1,0 \mathrm{mV}$ por década para o intervalo de concentração do salicilato entre $7,0 \times 10^{-7}-1,0 \times 10^{-1} \mathrm{~mol}$ de $\mathrm{L}^{-1}$. O eletrodo exibiu um rápido tempo de resposta $(\leq 20 \mathrm{~s})$ com limite de deteção $(\mathrm{LOD})$ de $5,0 \times 10^{-7} \mathrm{~mol} \mathrm{~L}^{-1}$ podendo ser empregado para faixa de $\mathrm{pH}$ entre 6,0 e 9,5. Foi aplicado com sucesso à determinação do íon salicilato em amostras reais.

The potentiometric response of salicylate electrode based on complex of (1,8-diamino-3,6dioxaoctane) nickel(II) was studied. The complex of 1,8-diamino-3,6-dioxaoctane nickel(II) [Ni(DADOO)] was used as carrier into plasticized polyvinyl chloride (PVC) membrane. The influence of several variables was investigated in order to optimize the potentiometric response and selectivity of the electrode. The resulting membrane electrode incorporating $29 \%$ PVC, $63 \%$ dioctylphthalate (DOP) as plasticizer, $2 \%$ methyltrioctylammonium chloride (MTOAC) as cationic additive and $6 \%$ carrier $\left(\right.$ all $\mathrm{m} / \mathrm{m}$ ) demonstrated a Nernstian response of $-59.5 \pm 1.0 \mathrm{mV} \mathrm{decade} \mathrm{d}^{-1}$ over the concentration range of $7.0 \times 10^{-7}-1.0 \times 10^{-1} \mathrm{~mol} \mathrm{~L}^{-1}$ salicylate. The electrode exhibited a fast response time $(\leq 20 \mathrm{~s})$ with detection limit of $5.0 \times 10^{-7} \mathrm{~mol} \mathrm{~L}^{-1}$, and can be used over a wide $\mathrm{pH}$ range of 6.0-9.5. It was successfully applied to the determination of salicylate ion in real samples.

Keywords: salicylate ion-selective electrode, PVC membrane, potentiometry, salicylate analysis, Ni-complex

\section{Introduction}

In the modern health care setting clinicians are increasingly dependent upon the reliable and rapid measurement of chemical variables for accurate diagnostic and therapeutic decisions. ${ }^{1}$ There is a perceived and increasing demand for simple, inexpensive and rapid

*e-mail: mazloumardakani@gmail.com analytical tests for detection of trace amounts of biologically and chemically important compounds. Potentiometric detection based on ion-selective electrodes (ISEs) as a simple method offers great advantages such as speed, and ease of preparation and procedure, relatively fast response reasonable selectivity, wide linear dynamic range and low cost. These characteristics have inevitably led to sensors for several ionic species and the list of available electrodes has grown substantially over the past years. ${ }^{2}$ ISEs have found 
wide spread use specially for the direct determination of ionic species in whole and diluted blood, serum, urine, tissue, and intercellular samples. ${ }^{3}$

Salicylate derivatives are commonly used as effective antimicrobial, antipyretic and analgesic agents. Aspirin, in particular, probably remains one of the most widely used drugs of any kind. Salicylate ion $\left(\mathrm{Sal}^{-}\right)$is the main hydrolyzed product of tablet aspirin or an aspirin-like substances, with are commonly used as effective analgesics. One should realize, however, that salicylates can be quite toxic if taken in large doses. Level in plasma higher than $2.2 \mathrm{mmol} \mathrm{L}^{-1}$ of salicylates are regarded as being toxic for patients. ${ }^{4}$ Therefore, finding simple methods for the determination of salicylate is still of considerable interest. The conventional analytical method for the detection of salicylate is based on the Trinder reaction, in which the simple salicylate reacts with ferric ions to form a colored complex in an acidic solution. This method always lacks adequate selectivity for the formation of other similar complexes. ${ }^{5}$ Several methods such as high performance liquid chromatography, ${ }^{6,7}$ fluorometric, ${ }^{8}$ phosphorimetric, ${ }^{9}$ luminescent, ${ }^{10}$ and biomimetic ${ }^{11}$ methods have recently been reported for its determination. Compared to the above mentioned methods, the ion-selective electrode is relatively simple in preparation, not requiring any sophisticated instrumentation and thus attracting remarkable attention for many years. ${ }^{12-17}$

This paper describes the use of the complex of 1,8-diamino-3,6-dioxaoctane nickel(II) percholorate [Ni(DADOO)] as an electroactive material for preparing salicylate-sensitive electrode. The potentiometric response properties, reproducibility and selectivity of electrodes were evaluated by the response potentials and selectivity coefficients. The salicylate-ion selective electrode exhibited significantly high sensitivity, stability, and selectivity for salicylate ion over many common ions. It was successfully used for determining salicylate ion in real samples.

\section{Experimental}

\section{Reagents}

PVC of high relative molecular weight, methyltrioctylammonium chloride (MTOAC), dibutylphthalate (DBP), sodium teraphenylborate (NaTPB), dioctylphthalate (DOP), were obtained from Merck (Darmstadt, Germany). The ionophore was prepared as follows. A stock solution of $1.0 \times 10^{-1} \mathrm{~mol} \mathrm{~L}^{-1} \mathrm{Sal}^{-}$was prepared by dissolving $1.6010 \mathrm{~g}$ of sodium salicylate in $100 \mathrm{~mL}$ of doubly distilled water. Working solutions were prepared by successive dilutions with doubly distilled water. All working solutions were buffered at $\mathrm{pH}$ 7.0. All anion solutions were prepared in doubly distilled water and solutions of different concentrations were made by serial dilution of $1.0 \times 10^{-1} \mathrm{~mol} \mathrm{~L}^{-1}$ stock solutions. Doubly-distilled water was used throughout all experiments. In order to prepare the pharmaceutical samples, tablets of different samples of aspirin were finely powdered. A precisely weighted portion of each sample was refluxed with $c a .50 \mathrm{~mL}$ of $5.0 \times 10^{-1} \mathrm{~mol} \mathrm{~L}^{-1} \mathrm{NaOH}$ for $1 \mathrm{~h}$. After being filtered, the solution was diluted to $250 \mathrm{~mL}$ in a volumetric flask and used for the determination of salicylate content by potentiometric and specrophotometric methods.

\section{Synthesis of 1,8-diamino-3,6-dioxaoctane nickel(II)} percholorate [Ni(DADOO)]

[Ni( 1,8 -diamino-3,6-dioxaoctane $)]\left(\mathrm{ClO}_{4}\right)_{2}$ [Ni(DADOO)] complex (Figure1) was obtained by the reaction of 1,8-diamino-3,6-dioxaoctane with $\mathrm{Ni}\left(\mathrm{ClO}_{4}\right)_{2} \cdot 6 \mathrm{H}_{2} \mathrm{O}$ in methanol and recrystallized from water. For the preparation of $\left[\left(\mathrm{Ni}\left(\mathrm{C}_{20} \mathrm{H}_{24} \mathrm{~N}_{2} \mathrm{O}_{4}\right)\right]\left(\mathrm{ClO}_{4}\right)_{2}\right.$ complex, to a solution of (1,8-diamino-3,6-dioxaoctane) nickel(II) percholorate $(5 \mathrm{mmol})$ in $\mathrm{MeOH}(100 \mathrm{~mL})$, a solution of 2-hydroxy benzaldehyde (10 mmol) in $\mathrm{MeOH}(50 \mathrm{~mL})$ was added and the resulting mixture was stirred for $c a .24 \mathrm{~h}$ at reflux. The brown solid product was filtered off, washed with $\mathrm{MeOH}$ and dried over fused $\mathrm{CaCl}_{2}$ in desiccators. The product was crystallized from hot $\mathrm{MeOH}$. Anal. calc. for $\left[\mathrm{C}_{20} \mathrm{H}_{24} \mathrm{Cl}_{2} \mathrm{~N}_{2} \mathrm{NiO}_{12}\right]$ : C, 39.12; H, 3.94; N, 4.56; Ni, 9.56. Found: C, 39.02; H, 3.84; N, 4.63; Ni, 9.41\%; yield: $c a$. $58 \% ; v_{\mathrm{C}=\mathrm{N}} 1610 \mathrm{~cm}^{-1} ; \mathrm{d} \leftrightarrow \mathrm{d} 492 \mathrm{~nm}$ (in MeOH solution); $\mu_{\mathrm{B}}-0.009$ B.M; $\Lambda_{\mathrm{M}} 250\left(\Omega^{-1} \mathrm{~cm}^{-1} \mathrm{M}^{-1}\right)$.

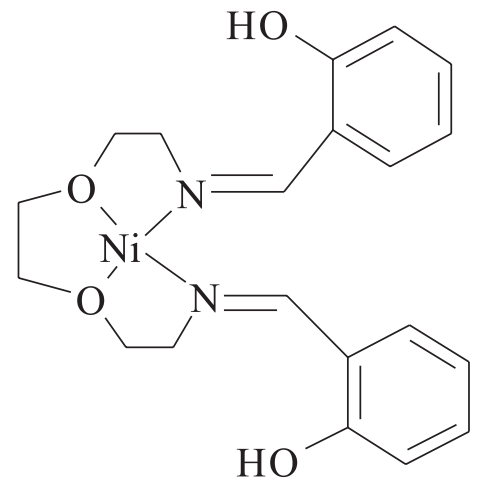

Figure 1. Structural representation of the compound of 1,8-diamino-3,6dioxaoctane nickel(II) [Ni(DADOO)] used as ionophore in the PVCmembrane $\mathrm{Sal}^{-}$-selective electrode.

\section{Electrode preparation}

A mixture of PVC, plasticizer and the membrane additive with a total mass of $100 \mathrm{mg}$ was dissolved in about $10 \mathrm{~mL}$ of 
Table 1. Optimized membrane compositions and their potentiometric response properties in salicylate-selective electrode; values in table are mass ratio percent

\begin{tabular}{|c|c|c|c|c|c|c|}
\hline No. & PVC \% & Plasticizer $\%$ & Ionophore & Additive $\%$ & $\begin{array}{c}\text { Slope / } \\
\mathrm{mV} \text { decade }^{-1}\end{array}$ & $\begin{array}{l}\text { Linear dynamic } \\
\text { range / mol L }{ }^{-1}\end{array}$ \\
\hline 1 & 32 & 62 (DOP) & 6 & 0 & -40.8 & $1.0 \times 10^{-1}-6.0 \times 10^{-5}$ \\
\hline 2 & 30 & 61 (DOP) & 7 & 2 (MTOAC) & -57.9 & $1.0 \times 10^{-1}-1.0 \times 10^{-6}$ \\
\hline 3 & 30 & 60 (DBP) & 8 & 2 (MTOAC) & -50.9 & $1.0 \times 10^{-1}-1.0 \times 10^{-7}$ \\
\hline 4 & 32 & 60 (DBP) & 7.5 & 0.5 (MTOAC) & -54.6 & $1.0 \times 10^{-1}-1.0 \times 10^{-6}$ \\
\hline 5 & 29 & 63 (DOP) & 6 & 2 (MTOAC) & -59.5 & $1.0 \times 10^{-1}-7.0 \times 10^{-7}$ \\
\hline 6 & 30 & 62 (DOS) & 6 & 2 (MTOAC) & -62.1 & $1.0 \times 10^{-1}-1.0 \times 10^{-6}$ \\
\hline 7 & 33 & 60 (DBS) & 5 & 2 (MTOAC) & -46.7 & $1.0 \times 10^{-1}-1.0 \times 10^{-7}$ \\
\hline 8 & 32 & 60 (DOP) & 6 & 2 (MTOAC) & -60.9 & $1.0 \times 10^{-1}-1.0 \times 10^{-6}$ \\
\hline 9 & 32 & 60 (DOP) & 6.5 & 1.5 (MTOAC) & -56.2 & $1.0 \times 10^{-1}-1.0 \times 10^{-6}$ \\
\hline 10 & 31 & 60 (DBS) & 7 & 2 (NaTPB) & -18.8 & $1.0 \times 10^{-1}-3.0 \times 10^{-5}$ \\
\hline
\end{tabular}

THF. To this mixture, the ionophore [Ni(DADOO)] complex was added and the solution was mixed well. Membrane compositions are listed in Table 1. The optimum composition of the membrane was $29.0 \mathrm{wt} . \%$ PVC, $63.0 \mathrm{wt} . \%$ DOP, $6.0 \mathrm{wt} . \%$ ionophore, $2.0 \mathrm{wt} . \%$ MTOAC as cationic additive. The resulting mixture was poured into a small flat bottom dish of $2 \mathrm{~cm}$ diameter, covered with a filter paper and the solvent was allowed to evaporate at room temperature. A pyrex tube ( $5 \mathrm{~mm}$ i.d.) was dipped into the mixture for about $10 \mathrm{~s}$ so that a nontransparent membrane was formed. Then, the tube was then pulled out from the mixture and kept at room temperature for $24 \mathrm{~h}$. The tube was then filled with the internal solution $1.0 \times 10^{-1} \mathrm{~mol} \mathrm{~L}^{-1} \mathrm{Sal}^{-}$. The first conditioning time was approximately $24 \mathrm{~h}$ and then 20-30 min for successive uses. A silver/silver chloride electrode was used as an internal reference electrode.

\section{Apparatus}

The potential measurements were carried out at $25 \pm 1{ }^{\circ} \mathrm{C}$ using a digital $\mathrm{pHmeter}(\mathrm{mV}), \mathrm{Zag}$ Chimi, Iran, by setting up the following assembly:

$\mathrm{Ag}|\mathrm{AgCl}|$ internal solution $\left(\mathrm{KCl} 3.0 \mathrm{~mol} \mathrm{~L}^{-1}, \mathrm{Sal}^{-}\right.$ $\left.1.0 \times 10^{-1} \mathrm{~mol} \mathrm{~L}^{-1}\right) \mid \mathrm{PVC}$ membrane | test solution $\|$ SCE

A saturated calomel electrode (SCE, Azar electrode, Iran) with a fiber junction was used as the external reference electrode. Activities were calculated according to the Debye-Hückel procedure. ${ }^{18}$ For construction of the calibration curve, concentration instead of activity was used. The $\mathrm{pH}$ of the sample solution was monitored simultaneously with a conventional glass $\mathrm{pH}$ electrode (Metrohm, Swittzerland). The performance of the electrode was investigated by measuring its potential in salicylate solutions prepared in the concentration range $1.0 \times 10^{-8}-1.0 \times 10^{-1} \mathrm{~mol} \mathrm{~L}^{-1}$ by serial dilution at constant $\mathrm{pH}$. All solutions were freshly prepared by dilution from the stock standard solution, $1.0 \times 10^{-1} \mathrm{~mol} \mathrm{~L}^{-1}$, with doubly- distilled water. The solutions were stirred and potential readings recorded when they became stable. The data were plotted as observed potential $v s$. the logarithm of the $\mathrm{Sal}^{-}$concentration at constant $\mathrm{pH}(\mathrm{pH}=7.0)$.

\section{Determination of selectivity coefficient}

The selectivity factor, $\mathrm{K}^{\mathrm{pot}}$ is a measure of the preference of the ion-selective electrode for the interfering ion A relative to the primary ion $\mathrm{Sal}^{-}$to be measured. A selectivity factor below 1 indicates that the preference is for the primary ion $\mathrm{Sal}^{-}$. Selectivities of solvent polymeric membrane ion-selective electrodes are quantitatively related to equilibria at the interface between the sample and the electrode membrane. Selectivity coefficients are determined experimentally using the separate solution method (SSM) and fixed interference method (FIM). In the separate solution method, potential values obtained for measuring (primary) ion and the interfering ion, both determined in pure single electrolyte solutions, are compared using the Nicolsky-Eisenmann equation. In fixed interference method, the potential of a cell comprising an ion-selective electrode and a reference electrode is measured with solutions of constant level of interference ion, $a_{A}$, and varying activity of primary ion $\mathrm{a}_{\mathrm{Sal}}$. The potential values obtained are plotted $v s$. the concentration of the primary ion. The intersection of the extrapolation of the linear portions of this curve will indicate the value $\mathrm{a}_{\mathrm{A}}$ which is to be used to calculate $\mathrm{K}^{\mathrm{pot}}$. Potentiometric selectivity coefficients for several anions relative to salicylate ion were determined by the fixed interferences method (FIM). ${ }^{19,20}$

\section{Results and Discussion}

The $[\mathrm{Ni}(\mathrm{DADOO})]$ complex as a carrier was found to be highly responsive to salicylate with respect to several other ions. Therefore, we studied in detail the performance of the plasticized PVC membrane containing this ionophore for salicylate in aqueous solutions. Preliminary experiments 
were carried out to obtain an optimum membrane composition. The optimized membrane was used to test the performance of the membrane characteristics.

\section{The influence of membrane composition}

In a preliminary experiment, membranes with and without carrier were constructed. The membrane with no carrier displayed insignificant selectivity toward salicylate and its response was not reliable. However, in the presence of the proposed carrier, the optimized membrane demonstrated Nernstian response and remarkable selectivity for salicylate over several common inorganic and organic anions. The preferential response toward $\mathrm{Sal}^{-}$is believed to be associated with the coordination of salicylate with the central metal ion of the carrier.

Besides the critical role of the nature of the ion-carrier in preparing membrane-selective sensors, some other important features of the PVC membrane such as the amount of the ionophore, the nature of the solvent mediator (plasticizer), the plasticizer/PVC ratio, and especially the nature of additives used are known to significantly influence the sensitivity and selectivity of ion selective electrodes..$^{21-23}$ Thus, several membrane compositions were investigated by varying the ratio of PVC, plasticizer, and the membrane active material, [Ni(DADOO)] complex (Table 1). The potentiometric response of the membrane was greatly improved in the presence of lipophilic cationic additive, MTOAC. Generally, better response characteristics were observed with an ionophore/MTOAC weight ratio of about 3.5 , which corresponds to a mol ratio of about 3.4. It is known that lipophilic salts not only reduce the membrane resistance, but also enhance the response behavior and selectivity, and reduce interferences from sample anions..$^{24,25}$ The presence of lipophilic ionic sites is beneficial for both neutral carrier and charged carrier-based ion-selective electrodes. ${ }^{26,27}$ Neutral carrier based cation-selective electrodes require lipophilic ionic sites with a charge sign opposite to that of the primary ion for obtaining Nernstian responses. ${ }^{28,29}$ However, for the charged carrier based ionselective electrodes, the charged sign of the ionic sites that gives the highest potentiometric selectivities depends on the charge of the ionophore, charge of the primary and interfering ions as well as on the stoichiometry of their complexes with the ionphore. ${ }^{30}$ Therefore, from the different effect that the charge of the added ionic sites has on neutral and charged carrier based ion-selective electrodes, the carrier mechanism may be evaluated by investigating membranes that contain ionic sites of opposing charges. ${ }^{31,32}$

As it is obvious from Table 1, among four different plasticizers used, DOP was a more effective solvent mediator in preparing the salicylate selective electrode. It should be noted that the nature of the plasticizer influences both the dielectric constant of the membrane and the mobility of the ionophore and its complex. Initially, plasticizers were applied to the polymer matrix in order to decrease its viscosity and provide mobility of the membrane constituents within the membrane phase. In relation to the role of plasticizer in a PVC membrane, it should be noted that a plasticizer acts as a membrane solvent, affecting membrane selectivity through both extraction of ions into organic phase and influencing their complexation with the ionophore.

The critical response characteristics of the proposed electrode were investigated according to IUPAC recommendations..$^{29,30}$ The membrane with a composition of $6 \%$ ionophore, $63 \%$ DOP, $29 \%$ PVC, $2 \%$ MTOAC generated a stable potential response in solutions containing $\mathrm{Sal}^{-}$after conditioning for $24 \mathrm{~h}$ in a $1.0 \times 10^{-1} \mathrm{~mol} \mathrm{~L}^{-1}$ $\mathrm{Sal}^{-}$solution.

Lipophilic ionic additive is a salt of non-exchangeable lipophilic anion/cation and an exchangeable counter ion. Ionic sites provide electroneutrality of the membrane with neutral ionic carriers so that no significant amount of counter ions can be co-extracted into the membrane together with primary ion. Therefore, the membrane is permeable only for ions of the same charge sign as primary ion (Donnan exclusion) and demonstrates theoretical Nernstian response. Moreover, lipophilic ionic sites reduce electrical resistance of the membrane, which is especially important for micro-dimensional electrodes.

\section{Response characteristics of the electrodes}

The potential response of the optimized salicylateselective electrode to varying concentrations of $\mathrm{Sal}^{-}$ions was examined. All the emf values were corrected for liquid junction potential using the Henderson equation. The average slope of the calibration plot resulted $-59.5 \pm 1.0 \mathrm{mV}$ decade $^{-1}$. The calibration plot is shown in Figure 2; it indicates a linear range from $7.0 \times 10^{-7}$ to $1.0 \times 10^{-1} \mathrm{~mol} \mathrm{~L}^{-1}$. The practical limit of detection, defined as the concentration of salicylate ion obtained from the intersection of two extrapolated segments of the calibration graph, was about $5.0 \times 10^{-7} \mathrm{~mol} \mathrm{~L}^{-1}$. The optimum equilibration times for salicylate-selective electrode in the presence of $1.0 \times 10^{-1} \mathrm{~mol} \mathrm{~L}^{-1}$ sodiun salicylate was $24 \mathrm{~h}$, after which the electrode would generate stable potentials in contact with $\mathrm{Sal}^{-}$solutions.

The stability and reproducibility of the electrodes were also tested. The standard deviation of 20 replicate measurements at $1.0 \times 10^{-1}, 1.0 \times 10^{-2}$ and $1.0 \times 10^{-3} \mathrm{~mol} \mathrm{~L}^{-1} \mathrm{Sal}^{-}$ 


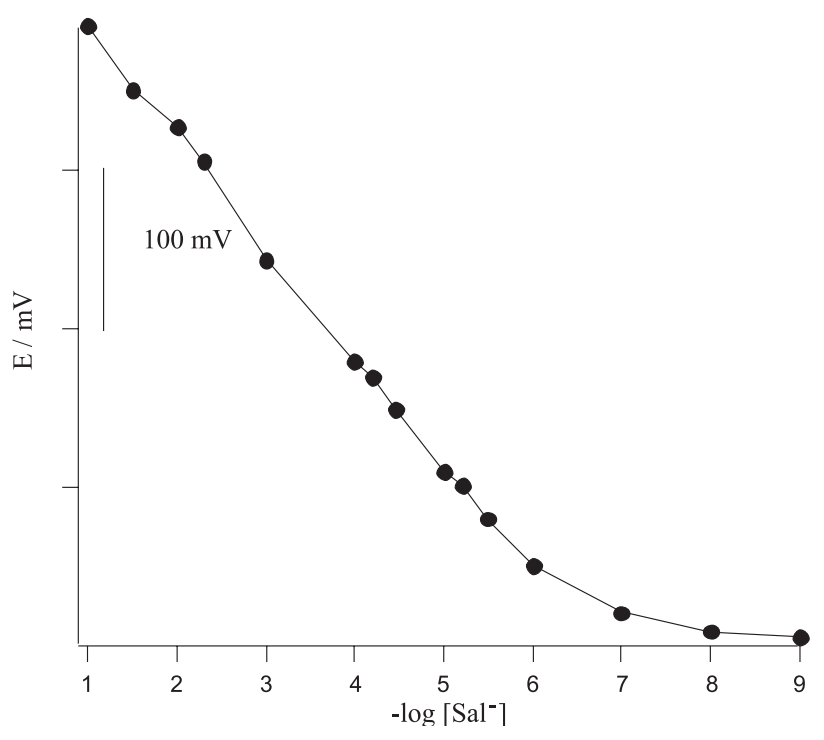

Figure 2. Potentiometric response of the salicylate-selective electrode to salicylate using optimized membrane electrode.

were $\pm 0.4, \pm 0.8$ and $\pm 1.0 \mathrm{mV}$, respectively. The signal stability was good, i.e., $3 \mathrm{mV} \mathrm{h}^{-1} .^{33}$ The long-term stability of the electrode was studied by periodically re-calibrating in standard solutions and calculating the response slope over the range of $1.0 \times 10^{-8}-1.0 \times 10^{-1} \mathrm{~mol} \mathrm{~L}^{-1}$.

The effect of the $\mathrm{pH}$ of the test solution on the response of the membrane electrode was examined at $\mathrm{Sal}^{-}$ concentration $1.0 \times 10^{-2} \mathrm{~mol} \mathrm{~L}^{-1}$. The $\mathrm{pH}$ was adjusted with dilute hydrochloric acid and sodium hydroxide as required. As illustrated in Figure 3 the potentials remain constant within a $\mathrm{pH}$ range of approximately 6.0-9.5. Variation of the potential at $\mathrm{pH}<6.0$ could be related to protonation of $[\mathrm{Ni}(\mathrm{DADOO})]$ in the membrane phase, which results in a loss of its ability to interact with $\mathrm{Sal}^{-}$ions. At higher $\mathrm{pH}>9.5$, the potential drop (negative slope) may be because of interference of the hydroxide ions. In high $\mathrm{pH}$ media,

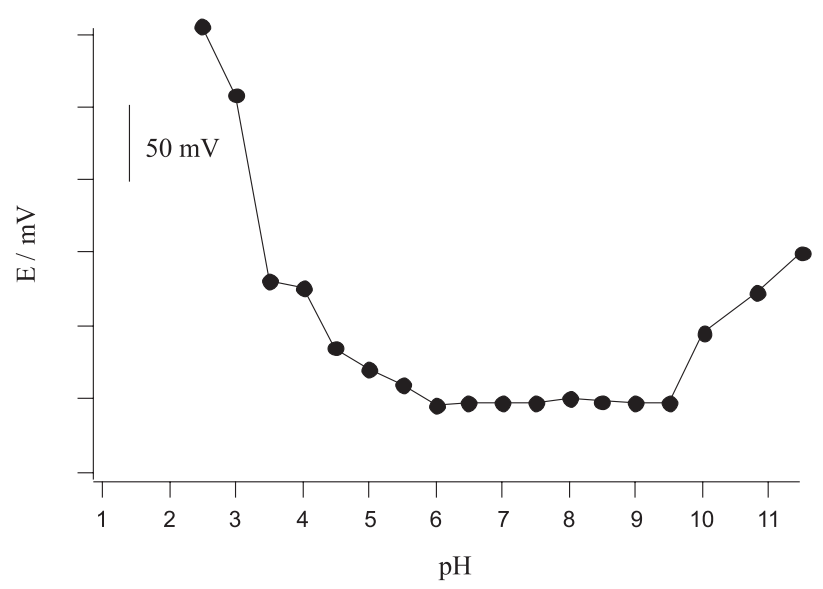

Figure 3. The $\mathrm{pH}$ response of the membrane electrode at $1.0 \times 10^{-2} \mathrm{~mol} \mathrm{~L}^{-1}$ salicylate concentration. hydroxide ion will compete with salicylate ion for the cation site in the membrane.

The response time, defined as the time elapsed from the dipping of the electrode in the solution until the equilibrium potential was reached, varied from 10 to $15 \mathrm{~s}$ depending on the analyte concentration. The response time was faster when the concentration was higher. The actual potential vs. time traces is shown in Figure 4. The sensing behavior of the membrane electrode did not depend on whether the potentials were recorded from low to high concentrations or vice versa.

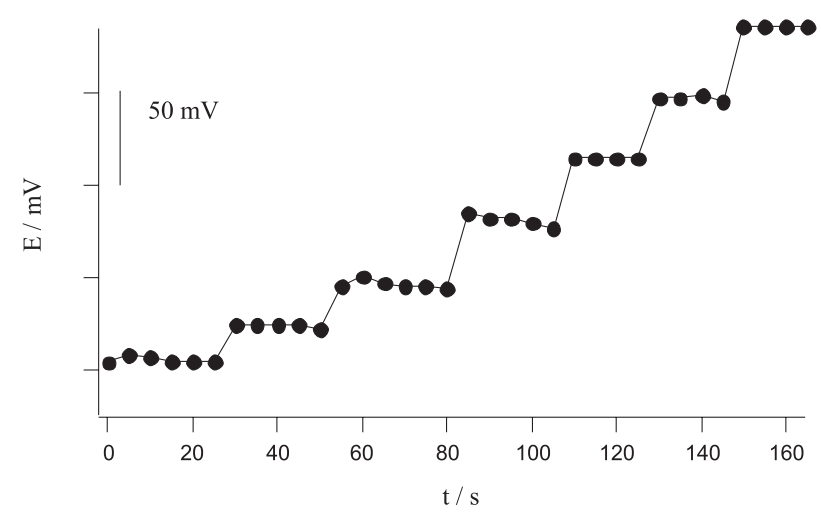

Figure 4. Response time of the membrane electrode for salicylate with changes of concentration from $1.0 \times 10^{-7} \mathrm{~mol} \mathrm{~L}^{-1}$ to $1.0 \times 10^{-1} \mathrm{~mol} \mathrm{~L}^{-1}$.

The influence of the concentration of internal solution on the potential response of the salicylate-selective electrode was studied and the results showed the concentration of the internal solution does not cause any significant difference in the potential response of the electrodes, except for an expected change in the intercept of the resulting Nernstian plots (Figure 5).

The electrode was tested over a period of two months to investigate stability. During this period the electrode was used daily and was stored in $1.0 \times 10^{-1} \mathrm{~mol} \mathrm{~L}^{-1} \mathrm{Sal}^{-}$ solution when not in use. Before any measurements, the electrode was conditioned in $1.0 \times 10^{-1} \mathrm{~mol} \mathrm{~L}^{-1} \mathrm{NaSal}$ for approximately 20-30 $\mathrm{min}$. The slopes of the electrode response were reproducible to within $\pm 5 \mathrm{mV} /$ decade over a period of two months. Storage of the electrode in solution for extended periods, however, especially in stirred solution, resulted in a slight gradual decrease in the slope, as is usual for many plasticized PVC membranes, probably as a result of leaching of the ionophore from the membrane. The characteristic properties of the optimized membrane are summarized in Table 2.

\section{Potentiometry selectivity coefficient}

The selectivity of the proposed salicylate ion selective electrode over other anions $\left(\mathrm{A}^{-}\right)$was important. Their 


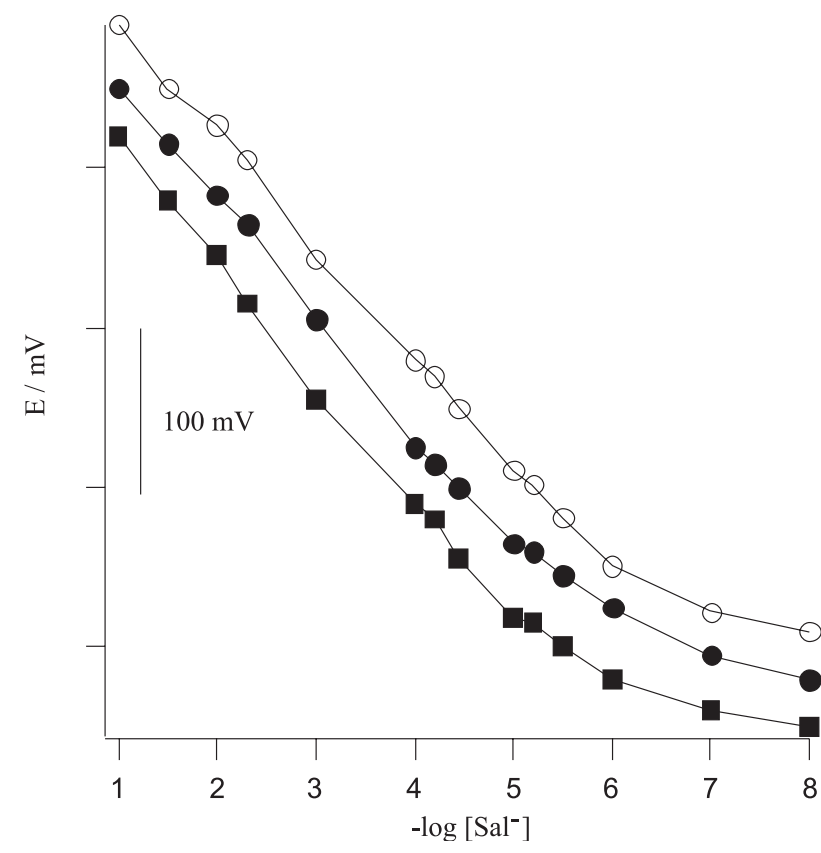

Figure 5. The influence of internal solution concentration on the potential response of the optimized Sal--ISE: $(O) 1.0 \times 10^{-1} \mathrm{~mol} \mathrm{~L}^{-1}$, (•) $1.0 \times 10^{-2} \mathrm{~mol} \mathrm{~L}^{-1},(\boldsymbol{\square}) 1.0 \times 10^{-3} \mathrm{~mol} \mathrm{~L}^{-1}$.

Table 2. Characteristics of optimized Sal-ISE

\begin{tabular}{ll}
\hline Linear range / $\mathrm{mol} \mathrm{L}^{-1}$ & $7.0 \times 10^{-7}-1.0 \times 10^{-1}$ \\
Slope / $\mathrm{mV}$ decade & -1 \\
$\mathrm{pH}$ range & -59.5 \\
precision & $6.0-9.5$ \\
& $\begin{array}{l}\text { at concentrations of } 1.0 \times 10^{-1}, 1.0 \times 10^{-2}, \\
\text { and } 1.0 \times 10^{-3} \mathrm{Sal}^{-} \text {standard deviations } \\
\text { were of } \pm 0.4 \text { and } \pm 0.8 \text { and } \pm 1.0 \mathrm{mV}\end{array}$ \\
Detection limit / $\mathrm{mol} \mathrm{L}^{-1}$ & $5.0 \times 10^{-7}$ \\
Lifetime / month & $>2$ \\
Response time / & $10-15$ \\
\hline
\end{tabular}

potential responses were investigated in the presence of a wide variety of interfering foreign anions using the mixed solution method (MSM). ${ }^{34,20}$ Potentiometric selectivity coefficients $\left(\mathrm{K}_{\text {Sal, }}^{\mathrm{pot}}\right.$ ) describing the preference of the membrane for an interfering ion $\mathrm{A}^{-}$relative to $\mathrm{Sal}^{-}$were determined by the fixed interference method (FIM) and separate solution method (SSM). The selectivity coefficient for various anions was evaluated by the mixed solution method with a fixed concentration of interference $\left(1.0 \times 10^{-1} \mathrm{~mol} \mathrm{~L}^{-1}\right)$ and varying amounts of $\mathrm{Sal}^{-}$concentrations. Table 3 lists the potentiometric selectivity coefficient data of the sensor for several anions relative to $\mathrm{Sal}^{-}$. The selectivity coefficients clearly indicate that the electrode is selective to salicylate over a number of other inorganic and organic anions. As it is evident from the data in Table 3 the electrode based on [Ni(DADOO)]
Table 3. Selectivity coefficients determined by use of the separate solution method (SSM) and fixed interference method (FIM) for the salicylateselective electrode

\begin{tabular}{|c|c|c|}
\hline Interferent ion & $\log \mathrm{K}^{\mathrm{pot}}{ }_{\text {sal. }}-(\mathrm{SSM})$ & $\log \mathrm{K}^{\mathrm{pot}}{ }_{\text {sal.A }}-(\mathrm{FIM})$ \\
\hline $\mathrm{F}^{-}$ & -4.7 & -2.9 \\
\hline $\mathrm{Cl}^{-}$ & -2.0 & -2.8 \\
\hline $\mathrm{BrO}_{3}^{-}$ & -2.3 & -2.3 \\
\hline $\mathrm{IO}_{3}^{-}$ & -3.3 & -2.8 \\
\hline Citrate & -2.2 & -3.2 \\
\hline $\mathrm{C}_{2} \mathrm{O}_{4}^{2-}$ & -3.9 & -3.6 \\
\hline $\mathrm{HCO}_{3}^{-}$ & -2.7 & -2.6 \\
\hline $\mathrm{S}_{2} \mathrm{O}_{3}^{2-}$ & -3.6 & -3.1 \\
\hline $\mathrm{CO}_{3}^{2-}$ & -2.5 & -2.2 \\
\hline $\mathrm{ClO}_{4}^{-}$ & -3.6 & - \\
\hline $\mathrm{ClO}_{3}^{-}$ & -2.7 & -2.8 \\
\hline $\mathrm{SO}_{4}^{2-}$ & -1.9 & -2.1 \\
\hline $\mathrm{NO}_{2}^{-}$ & -2.2 & -2.2 \\
\hline $\mathrm{HPO}_{4}^{2-}$ & -3.2 & -2.4 \\
\hline $\mathrm{NO}_{3}^{-}$ & -3.9 & -3.4 \\
\hline $\mathrm{I}^{-}$ & -3.8 & -3.5 \\
\hline $\mathrm{IO}_{4}^{-}$ & -1.9 & -2.2 \\
\hline $\mathrm{OAc}^{-}$ & -4.0 & -3.5 \\
\hline $\mathrm{SCN}^{-}$ & -3.7 & -3.3 \\
\hline $\mathrm{N}_{3}^{-}$ & -1.8 & -2.0 \\
\hline${ }^{\mathrm{a} B e n z^{-}}$ & -2.7 & -2.9 \\
\hline${ }^{\mathrm{b}} \mathrm{Me}^{-} \mathrm{Sal}^{-}$ & -2.8 & -2.6 \\
\hline
\end{tabular}

a) Benzoate; b) Methyl salicylate.

has relatively high selectivity toward $\mathrm{Sal}^{-}$relative to several common anions. This is most probably due to the weak interaction between these anions and the ionophore. It is interesting to note that the observed selectivity pattern for the Sal--ISE significantly differs from the so-called Hofmeister selectivity sequence. According to the tabulated data in Table 3, the interfering effect of the ions is in the following order:

$\mathrm{N}_{3}^{-}>\mathrm{SO}_{4}{ }^{2-}>\mathrm{IO}_{4}^{-}=\mathrm{NO}_{2}^{-}=\mathrm{CO}_{3}^{2-}>\mathrm{BrO}_{3}^{-}>\mathrm{HPO}_{4}{ }^{2-}>$ $\mathrm{HCO}_{3}^{-}=\mathrm{m}-\mathrm{Sal}>\mathrm{Cl}^{-}=\mathrm{IO}_{3}^{-}=\mathrm{ClO}_{3}^{-}>\mathrm{F}^{-}=\mathrm{Benz}^{-}>\mathrm{S}_{2} \mathrm{O}_{3}{ }^{2-}>$ $\mathrm{SCN}^{-}>\mathrm{NO}_{3}^{-}>\mathrm{I}^{-}=\mathrm{OAc}^{-}>\mathrm{ClO}_{4}^{-}=\mathrm{C}_{2} \mathrm{O}_{4}{ }^{2-}$.

The electrode demonstrates a significant deviation in selectivity from the Hofmeister series, ${ }^{35,36}$ large lipophilic anions $>\mathrm{ClO}_{4}^{-}>\mathrm{SCN}^{-}>\mathrm{I}^{-}>\mathrm{NO}_{3}^{-}>\mathrm{Br}^{-}>\mathrm{N}_{3}^{-}>\mathrm{NO}_{2}^{-}>$ $\mathrm{Cl}^{-}>\mathrm{OAc}^{-}>\mathrm{SO}_{4}{ }_{4}^{2-}$, A theoretical treatment of liquid anionexchanger membranes has shown that this kind of behavior is typical of dissociated anion-exchangers in which the complexation between the cationic sites and the counter ions in the membrane phase is negligible. The selectivity 
Table 4. Comparison of the potentiometric parameters of the proposed $\mathrm{Sal}^{-}$-selective electrode with other $\mathrm{Sal}^{-}$-selective electrodes

\begin{tabular}{|c|c|c|c|c|c|c|c|c|c|}
\hline $\mathrm{A}^{-}$ & $\begin{array}{l}\text { Proposed } \\
\text { Sal--ISE }\end{array}$ & Ref. 11 & Ref. 12 & Ref. 28 & Ref. 38 & Ref. 39 & Ref. 40 & Ref. 41 & Ref. 42 \\
\hline $\begin{array}{l}\text { Nernstian Slope, } \\
\mathrm{mV} \text { decade }^{-1}\end{array}$ & $-59.5 \pm 1.0$ & $-60.0 \pm 2$ & -55 & $-59.6 \pm 1.0$ & $\begin{array}{l}\text { Ionophores (I, II, III, IV, V } \\
\text { respectively) })^{\mathrm{a}},-50 \pm 2 \\
-54 \pm 1,-53 \pm 2 \\
-41 \pm 1,-41 \pm 1\end{array}$ & -58.1 & $-59.1 \pm 1.0$ & $-59.6 \pm 1.0$ & -59.3 \\
\hline Linear range, $\mathrm{mol} \mathrm{L}^{-1}$ & $\begin{array}{l}7.0 \times 10^{-7} \\
\text { to } 1.0 \times 10^{-1}\end{array}$ & $\begin{array}{l}1.0 \times 10^{-3} \\
\text { to } 1.0 \times 10^{-1}\end{array}$ & $\begin{array}{l}1.0 \times 10^{-5} \\
\text { to } 1.0 \times 10^{-1}\end{array}$ & $\begin{array}{l}1.0 \times 10^{-5} \\
\text { to } 1.0 \times 10^{-1}\end{array}$ & $\begin{array}{l}\left(2.5 \times 10^{-4} \text { to } 1.0 \times 10^{-1}\right) \\
\left(1.0 \times 10^{-4} \text { to } 1.0 \times 10^{-1}\right) \\
\left(8.0 \times 10^{-5} \text { to } 1.0 \times 10^{-1}\right) \\
\left(3.0 \times 10^{-4} \text { to } 1.0 \times 10^{-1}\right) \\
\left(3.0 \times 10^{-4} \text { to } 1.0 \times 10^{-1}\right)\end{array}$ & $\begin{array}{c}1.0 \times 10^{-6} \\
\text { to } 1.0\end{array}$ & $\begin{array}{c}1.0 \times 10^{-6} \\
\text { to } 1.0\end{array}$ & $\begin{array}{c}1.0 \times 10^{-6} \\
\text { to } 1.0\end{array}$ & $\begin{array}{l}9.0 \times 10^{-7} \\
\text { to } 1.0 \times 10^{-1}\end{array}$ \\
\hline $\begin{array}{l}\text { Limit of detection, } \\
\mathrm{mol} \mathrm{L}^{-1}\end{array}$ & $5.0 \times 10^{-7}$ & $6.0 \times 10^{-4}$ & $1.0 \times 10^{-5}$ & $5.0 \times 10^{-6}$ & $\begin{array}{c}8.0 \times 10^{-5}, 4.0 \times 10^{-5}, \\
1.3 \times 10^{-5}, 8.0 \times 10^{-5}, \\
8.0 \times 10^{-5}\end{array}$ & $8.0 \times 10^{-7}$ & $5.0 \times 10^{-7}$ & $5.0 \times 10^{-7}$ & $5.0 \times 10^{-7}$ \\
\hline $\begin{array}{l}\text { Response } \\
\text { time, s }\end{array}$ & $10-15$ & $30-300$ & $120-1200$ & $5-10$ & 4 & $\leq 10$ & 10 & 10 & 15 \\
\hline $\begin{array}{l}\text { Interferent ions } \\
\mathrm{K}^{\text {pot }}{ }_{\mathrm{A}, \text { Sal }}>1.0 \times 10^{-2}\end{array}$ & - & $\mathrm{I}^{-}$, benzoate & $\begin{array}{c}\mathrm{IO}_{4}^{-} \\
\mathrm{I}^{-}, \mathrm{SCN}^{-} \\
\mathrm{ClO}_{4}^{-}, \mathrm{Br}^{-}\end{array}$ & $\begin{array}{l}\mathrm{ClO}_{4}^{-}, \mathrm{I}^{-}, \\
\mathrm{Cr}_{2} \mathrm{O}_{7}^{2-}\end{array}$ & $\begin{array}{c}\mathrm{ClO}_{4}^{-}, \mathrm{SCN}^{-}, \mathrm{I}^{-}, \mathrm{ClO}_{4}^{-} \\
\mathrm{ClO}_{4}^{-}, \mathrm{ClO}_{4}^{-}, \mathrm{SCN}^{-}\end{array}$ & - & $\mathrm{ClO}_{4}^{-}$ & - & - \\
\hline
\end{tabular}

a Ionophore I, II, III, IV and V are: aluminum tetrakis-tert-butylphthalocyanine chloride (PćAlCl), PćCu, PćSnCl, PćLuOAc, PćDyOAc respectively. Tetrakis-tertbutylphthalocyanine is describe as Pć.

is completely described by the distribution coefficients of the various anions between the sample solution and the membrane phase. ${ }^{37}$ The reason that the selectivity coefficients of the proposed salicylate electrode do not comply with the Hofmeister series can be due to specific interaction of the anions with the metal center in the carrier used in this study, i.e. chemical recognition of the anions, and especially of salicylate, by the complex. From the data given in Table 3; it is immediately obvious that the $\mathrm{Sal}^{-}$-ISE is highly selective with respect to other inorganic and organic anions. This is most probably due to the weak interaction between other anions and the ionophore.

Table 4 lists the linear range, detection limit, slope, response time and selectivity coefficients of some of other salicylate-selective electrodes against proposed salicylateselective electrode for comparative purposes..$^{11,12,28,38-42}$ As can be seen from the Table 4, the selectivity coefficients obtained for the proposed electrode are superior to some reported for other $\mathrm{Sal}^{-}$-selective electrodes listed in Table 4. Linear range, Nernstian slope and limit of detection characteristics of the proposed $\mathrm{Sal}^{-}$-selective electrode is comparable with other Sal-selective electrode.

\section{Analytical applications}

The proposed membrane electrodes were found to work well under laboratory conditions. It can be seen that the amount of salicylate ion can be accurately determined from the electrode. The salicylate-selective electrode has also been applied to the determined of salicylate in drugs (aspirin tablets). It is known that the salicylate and its derivatives are extensively used as analgesics in many pharmaceutical preparations. The salicylate content of the final solution was determined by the proposed electrode using the standard addition method and also by spectrophotometric method as a reference method. ${ }^{43}$ The comparison of the results obtained from ten measurements and the certified value shows that the present electrode can be used in determination of Sal in real samples. The results are given in Table 5.

Table 5. Determination of salicylate in different Aspirin ${ }^{\circledR}$ tablets samples $(\mathrm{n}=10)$

\begin{tabular}{ccc}
\hline $\begin{array}{c}\text { Aspirin samples } \\
(\mathrm{mg} / \text { tablet })\end{array}$ & $\begin{array}{c}\text { Spectrophotometric } \\
\text { method }(\mathrm{mg} / \mathrm{tablet})\end{array}$ & $\begin{array}{c}\text { ISE } \\
(\mathrm{mg} / \mathrm{tablet})\end{array}$ \\
\hline 100 & $95.21 \pm 0.63$ & $92.10 \pm 0.45$ \\
325 & $311.0 \pm 2.8$ & $305.30 \pm 0.6$ \\
\hline
\end{tabular}

\section{Conclusions}

New salicylate-selective membrane electrode has been prepared using the complex of [Ni(DADOO)]. This electrode has shown to have good operating characteristics (Nernstian response, reasonable detection limit, relatively high selectivity, wide dynamic range and fast response). These characteristics and the typical applications presented in this paper make the electrode suitable for measuring the acetylsalicylic acid content in pharmaceutical samples without a significant interaction from concomitant anionic species. The results show that there was a coordination interaction between salicylate and 
the proposed carrier, which played an important role in the response characteristics and selectivity of the electrodes.

\section{Acknowledgments}

The authors express their appreciation to the Payam Noor University Research Councils (Ardakan Center) and the IUT Research Council and Excellence in Sensors for financial support of this research.

\section{References}

1. Singer, R.; Anal. Chem. 1987, 59, 113.

2. Bühlmann, P.; Pretsh, E.; Bakker, E.; Chem. Rev. 1998, 98, 1593.

3. Meyerhoff, M. E.; Trends Anal. Chem. 1993, 12, 257.

4. MacMahon, G. P.; Kelly, M. T.; Anal. Chem. 1998, 70, 409.

5. Trinder, P.; Biochem. J. 1954, 57, 301.

6. Moore, T. J.; Joseph, M. J.; Allen, B. W.; Coury, L. A.; Anal. Chem. 1995, 67, 1869.

7. MacMahon, G. P.; O’Connor, S. J.; Fitzgerald, D. J.; Roy, S. L.; Kelly, M. T.; J. Chromatogr., B: Anal. Technol. Biomed. Life Sci. 1998, 48, 469.

8. Navalon, A.; Blanc, R.; Olmo, M. D.; Vilchez, J. L.; Talanta 1999, 48, 469.

9. Lloyed, J .B. F.; Analyst 1978, 103, 775.

10. Arnaud, N.; Georges, J.; Analyst 1999, 124, 1075.

11. Hutchins, R. S.; Bansal, P.; Molina, P.; Alajarin, M.; Vidal, A.; Bachas, L. G.; Anal. Chem. 1997, 69, 1273.

12. Chaniotakis, N. A.; Park, S. B.; Meyerhoff, M. E.; Anal. Chem. 1989, 61,566

13. Creager, S. E.; Lawrence, K. D.; Tibbets, C. R.; J. Chem. Educ. 1995, 72, 274

14. Hisamoto, H.; Siswanta, D.; Niashara, H.; Suzuki, K.; Anal. Chim. Acta 1995, 304, 171.

15. Katso, T.; Mori, Y.; Talanta 1996, 43, 755.

16. Rover Jr., L.; Garcia, C. A. B.; Oliveira Neto, G.; Kubota, L. T.; Galembeck, F.; Anal. Chim. Acta 1998, 366, 103.

17. Radecki, J.; Stenka, I.; Dolusic, E.; Dehaen, W.; Electrochim. Acta 2006, 51, 2282.

18. Kamata, S.; Bhal, A.; Fakunaga, Y.; Marata, A.; Anal. Chem. 1998, 60, 2464

19. Bakker, E.; Pretsch, E.; Bühlmann, P.; Anal. Chem. 2000, 72, 1127.

20. Umezawa, Y.; Umezawa, K.; Sato, H.; Pure Appl. Chem. 1995, $67,507$.

21. Shamsipur, M.; Khayatian, G.; Tangestaninejad, S.; Electroanalysis 1999, 18, 1340.
22. Rouhollahi, A.; Shamsipur, M.; Anal. Chem. 1999, 71, 1350.

23. Farhadi, K. H.; Maleki, R.; Shamsipur, M.; Electroanalysis 2002, 14, 760 .

24. Mazloum-Ardakani, M.; Sheikhmohseni, M. A.; SalavatiNiasari, M.; Can. J. Anal. Sci. Spectrosc. 2008, 53, 163.

25. Huser, M.; Gehrlg, P. M.; Morf, W. E.; Simon, W.; Lindner, C.; Jeney, J.; Toth, K.; Pungor, E.; Anal. Chem. 1991, 63, 1380.

26. Schaller, U.; Bakker, E.; Spichiger, U. E.; Pretsch, E.; Anal. Chem. 1994, 66, 391.

27. Bakker, E.; Malinowska, E.; Schiller, R. D.; Meyerhoff, M. E.; Talanta 1994, 41, 881.

28. Mazloum-Ardakani, M.; Pourhakak, P.; Salavati-Niasari, M.; J. Braz. Chem. Soc. 2007, 18, 782.

29. Yajima, S.; Tohda, K.; Bühlmann, P.; Umezawa, Y.; Anal. Chem. 1997, 69, 1919.

30. Amemiya, S.; Bülhlmann, P.; Pretsch, E.; Rusterholz, B.; Umezawa, Y.; Anal. Chem. 2000, 72, 1618.

31. Bakker, E.; Bühlmann, P.; Pretsch, E.; Chem. Rev. 1997, 97, 3083.

32. Schaller, U.; Bakker, E.; Pretsch, E.; Anal. Chem. 1995, 67, 3123.

33. Buck, R. P.; Lindner, E.; Pure Appl. Chem. 1994, 66, 2527.

34. Srinivasan, K.; Rechnitz, G. A.; Anal. Chem. 1969, 41, 1203.

35. Badr, I. H. A.; Meyerhoff, M. E.; Hassan, S. S. M.; Anal. Chem. 1995, 67, 2613.

36. Morf, W. E.; The Principles of lon-Selective Electrodes and of Membrane Transport, Akademiai Kiaddo, Budapest, Elsevier: Amsterdarn, 1981.

37. Ammann, D.; Ion-Selective Electrodes, Springer Verlag: Berlin, 1986.

38. Leyzerovich, N. N.; Shvedene, N. V.; Bilkova, Y. N.; Tomilova, L. G.; Pletnev, I. V.; Electroanalysis 2001, 3, 246.

39. Mazloum-Ardakani, M.; Mashhadizadeh, M. H.; Karimi, M. A.; Iranpoor, F.; Azimi, M. S.; Salavati-Niasari, M.; Can. J. Anal. Sci. Spectrosc. 2006, 51, 323

40. Mazloum-Ardakani, M.; Jamshidpoor, M.; Naeimi, H.; Heidarnezhad, A.; Bull. Korean Chem. Soc. 2006, 27, 1127.

41. Mazloum-Ardakani, M.; Jalayer, M. S.; Safari, J.; Sadeghi, Z.; Zare, H. R.; Anal. Biochem. 2005, 341, 259.

42. En-Ping Luo.; Ya-Qing Chai; Ruo Yuan.; Jian-Yuan Dai.; Lan Xu.; Desalination 2009, 249, 615.

43. British Pharmacopoeia; University Press: Cambridge, vol. II, 1993.

Submitted: May 9, 2010 Published online: July 22, 2010 